\title{
A magyar szénhidrogéniparban előfordult katasztrófák, azok tanulságai és a megelőzés módozatai 2. rész
}

\section{Disasters in the Hungarian Hydrocarbon Industry, their Lessons Learned and Ways of Prevention, Part II}

A tanulmány második részében a szerzők rámutatnak arra, hogy a szénhidrogénipari üzemek a rájuk jellemző „fokozott tűz- vagy robbanásveszély" miatt a katasztrófavédelem kiemelt területének számítanak. A szénhidrogén-feldolgozás során az üzemekben előforduló balesetek nem múlnak el nyomtalanul, a környezetre, a technológiára és a müködtetőkre egyaránt nagy hatást gyakorolnak. A szerzők véleményét a feldolgozott események megerősítik a tekintetben, hogy a nagyobb ipari katasztrófák elkerüléséhez a hatóságoknak, a fejlesztőknek és az üzemeltetőknek közösen, a korábbi események tanulságait felhasználva a felkészülés és a megelőzés komplex módozatainak fejlesztésével mindig egy gondolattal a káresetek bekövetkezése előtt kell járniuk.

Kulcsszavak: katasztrófavédelem, szénhidrogénipar, kőolaj- és földgázkitörés, ipari katasztrófák, megelőzés

In the second part of the study the authors show that because of the high fire and explosion danger in hydrocarbon-processing plants, it is an emphasised area of disaster management. The accidents that happen during petroleum mining and in the

Nemzeti Közszolgálati Egyetem, doktorandusz, e-mail: andras.toth@katved.gov.hu, ORCID: https://orcid.org/00000002-7365-6620

2 Nemzeti Közszolgálati Egyetem, egyetemi tanár, e-mail: siposne.kecskemethy.klara@uni-nke.hu, ORCID: https:// orcid.org/0000-0002-4150-7823

Nemzeti Közszolgálati Egyetem, egyetemi docens, e-mail: endrodi.istvan@uni-nke.hu, ORCID: https://orcid. org/0000-0002-3376-1389 
plants do not elapse without a trace, they leave a great impact on the environment, the technology, and the operation. The authors' opinions are strengthened based on the examined cases concerning that in order to avoid bigger industrial disasters the authorities, the developers, and the operators together should always be one step ahead of the occurrence of disasters, using what they have learned from earlier accidents, and improving the complex methods of preparation and prevention.

Keywords: disaster management, hydrocarbon industry, petroleum and natural gas eruption, industrial accidents, prevention

\section{Tartályrobbanások, tartálytüzek}

A cikksorozat második részében a szénhidrogénipari balesetek adatbázisában rögzített tartályrobbanásokkal, tűzesetekkel folytatjuk a sort. Az események egy része keletkezési ok szerint természeti eredetü, például villámcsapás, de a legfőbb ok a technológiai fegyelem megsértése, emberi mulasztás, felelőtlenség, túlkapás, ami sokszor a hatalmas kárérték mellett sérülést és halált okozott a szénhidrogén-tárolás és -feldolgozás során.

\section{6, Ormándlak}

Halálos áldozattal járó tárolótartály-robbanás történt 1956. augusztus elején. A Zala megyei Ormándlak mellett, a 6-os tankállomáson, egy félig telt kőolajtartály tetején rendeltek el hegesztési munkálatokat. Egy tapasztalt olajipari hegesztő tartályrobbanásra hivatkozva megtagadta a munkát, letartóztatták. A 18 éves fiatal hegesztő nem mert ellenkezni, az utasítás alapján megkezdte a tartály hegesztését, amely felrobbant, halálát okozva. A hegesztősegéd súlyosan megsérült. ${ }^{4}$

\section{9, Répcelak}

A Szénsavtermelő Vállalat répcelaki telepén 1969. január 2-án 14 óra 23 perckor bekövetkezett a szén-dioxidot tároló tartály robbanása, ami a magyar olajipar egyik legsúlyosabb következményekkel járó, kilenc ember halálát követelő műszaki balesete. Hatan súlyosan, tizennégyen könnyebben sérültek. Szén-dioxid töltése közben, a nem megfelelő anyagból készült „ $C$ " jelü tartály robbant fel, amelynek a búvónyílás palástjában hengerelési (anyag-) hiba volt, és repedéseket idézett elő a túlzott próbanyomás. A robbanás a tartály anyagának ridegtörése miatt következett be. ${ }^{5} \mathrm{~A}$ baleset rámutatott arra, hogy elengedhetetlen a hegesztők egységes képzési rendszerének kidolgozása és jogszabályi keretek közötti rendezése. Akkor megalakult Hegesztő

4 Jáni János: A nyugdijas gellénházi olajipari szakember visszaemlékezése a gáz és tartályrobbanásra. Készült Jáni János és Tóth András telefonos megbeszélése alapján, feljegyzés, Zalaegerszeg, 2019. szeptember 18.

5 Kurucz István: Indulatok nélkül. A répcelaki robbanásról. Zalaegerszeg, Magyar Olajipari Múzeum Közleményei, 2009. 188. 
Minősítő Bizottság, amelynek titkársági feladatait és szakmai irányítását a Gépipari Technológiai Intézet Hegesztési Szakosztálya látta el. ${ }^{6}$

A hasonló balesetek megelőzésének egyik módozata az ipari üzemek kitelepítése a városközpontból, ezért megvizsgáltuk Répcelak településrendezési tervét. Kitünt, hogy az ipari, gazdasági övezet kialakítása, fejlesztése nehezen valósítható meg. A város történetileg kialakult jelentős üzemei közül a LINDE-LISS Kft. feltáró útja új fejlesztési területként jelenik meg, amely a jelenleg fásított zöldterület, valamint a vasúti átjárótól délkeletre fekvő terület egy része. A Répcelak 86-os főút - M86-os gyorsforgalmi út közötti rész és az ipari-gazdasági terület összekapcsolása a város déli lakóövezetének tehermentesítését, valamint biztonságát szolgálná a közúton szállított szén-dioxid, nitrogén gázok esetében. ${ }^{7}$

\section{9, Százhalombatta}

A Dunai Kőolajipari Vállalat (a továbbiakban: DKV) bitumentöltő parkjában az 559. sz. bitumentartályban 1979. július 11-én robbanás történt. A leürítés után a maradék bitumen túlhevült. A $420 \mathrm{~m}^{3}$-es útépítő bitumentartályból a kiszállítást követően a bitumen szintje a beépített hőmérő érzékelője alá csökkent, így a maradék 50 tonna bitumen hőmérsékletét nem lehetett ellenőrizni, túlhevült. A tartályban felgyülemlett éghető gőzök a bitumenszint csökkenésekor beszívott levegővel keveredve öngyulladásba mentek át és robbanásszerüen elégtek. A tartály palástja a fenéklemezről leszakadt, az égő bitumen a tartály védőudvarba ömlött, és kb. $600 \mathrm{~m}^{2}$ területen szétfolyt, veszélyeztetve a többi tele tartályt, a technológiai vezetékeket. A robbanáskor felszakadt tető búvónyílásán és mérőnyílásán fáklyaszerű égés jött létre.

\section{2, Százhalombatta}

1982. május 29-én 8 óra 28 perckor villámcsapás érte a DKV felső tárolójának területén álló, 2014-es jelü, 2000 köbméteres, állóhengeres, merevtetős, toluolt tartalmazó tartályt, amely közös védőgödörben állt egy azonos nagyságú gázbontó benzint ${ }^{8}$ tartalmazó másik tartállyal. A tartály felrobbant, teteje körülbelül 55 méter távolságra repült, s körülbelül 1500 négyzetméter területen égett a tartályban lévő és a védőgödörbe kifolyt toluol. Az elrepült tartálytető megrongálta a 2013-as jelü tartályt, annak teteje félig a tartályba lógott, és égett az ott tárolt gázbontó benzin is. A tüzeset során elégett 86 tonna toluol, 133 tonna gázbontó benzin. A szabvány előírása szerint a villámcsapás nem okozhatott volna tüzet. A vállalatnál kialakult és eltürt gyakorlat szerint a tartályokon valamilyen tetőnyílást szabadon hagytak,

Tóth András - Muhoray Árpád - Pellérdi Rezső: Magyarország jelentősebb ipari katasztrófái a veszélyhelyzet tervezés és kezelés szempontjából. Müszaki Katonai Közlöny, 29. (2019), 2. 21-39.

BFH Európa Kft.: Répcelak Város Településfejlesztési Koncepciója. 2015.

8 Városi gáz előállításához használt benzin. Fajtái: nehéz és könnyű gázbontó benzin. A könnyü gázbontó benzin lobbanáspontja [40-130 ${ }^{\circ} \mathrm{C}$ ]. Régen, a földgáz nélküli városokba, például Sopronba vasúton tartálykocsikban juttatták el a benzint, és a bontásával állítottak elő gázt, a „városi” gázt. 
Tóth András, Siposné Kecskeméthy Klára, Endrődi István: A magyar szénhidrogéniparban...

mert a légzőszelepek beszorulása esetén a kialakult vákuum megrongálja a tartálylemezt. A leszakadt tetőfedélen is bizonyíthatóan nyitva volt a mérő- és búvónyílás. ${ }^{9}$

2010, Csepel

A bázistelepen tartálytisztítási és karbantartási munkálatok közben robbanás történt az 5002-es jelü tartályban, anyagmaradék-eltávolítási művelet közben. A munkálatokat egy alvállalkozó kivitelező cége, annak munkatársai végezték. A tisztítás során a szükséges védőfelszereléseket használták, a tartályban dolgozó munkatárs levegőellátását a szabályok szerint oxigénpalackkal biztosították, valamint a megfelelö létszámú külső szakmai felügyelet is biztosított volt. A robbanást sztatikus feltöltődés vagy nem megfelelő munkaeszköz okozta szikraképződés idézte elő. A tűz oltását a létesítményi és hivatásos tűzoltóság rövid idő alatt befejezte. ${ }^{10}$

\section{2, Zalaegerszeg}

A Zalai Finomító T-1006 és T-506 jelü késztermék bitumentároló tartályokban bekövetkezett tűzesetek alapvető oka technológiai mulasztás volt, amelynek következtében levegő került a tartályokba, és a $\sim 200^{\circ} \mathrm{C}$ hőmérsékletű bitumen fölötti gáz-gőztér berobbant, és tűz keletkezett. A gyulladást elősegítette a tartályfedelekre és oldalfalakra kirakódott piroforos kokszbevonat. A levegő (oxigén) bejutása a T-1006 jelü tartályba nagy valószínűséggel a tartály oldalának aljáról elbontott és eltávolított mechanikus keverőberendezés helyén nyitva maradt lyukon történt. A tartály javítás utáni beüzemelése során nem gondoskodtak a bejutott levegő kiszorításáról. A T-506 jelü tartálynál a T-1006 robbanását követő technológiai utasítás módosítás következtében a nyitott mérö- és búvónyíláson beáramló levegő miatt nem érvényesült a zárt inertizált ${ }^{11}$ rendszerben a nitrogéngáz tüzmegelőző szerepe. ${ }^{12}$

\section{8, Zalaegerszeg}

A Zalai Finomító területén telephellyel rendelkező vállalkozás bitumen tárolására szolgáló tartályát túltöltötték, amely következtében 5-6 $\mathrm{m}^{3}$ bitumen végigfolyt a tartály palástján, majd az alumíniumlemez szerelvénydoboz szigetelésénél meggyulladt, égett. A szigetelés alá befolyt bitumenben az ott akkumulálódott hő hatására termikus bomlási reakció ment végbe, éghető gázok, gőzök szabadultak fel, metán,

Kiss Imre: Tartályégetés Százhalombattán. Tüzoltó Múzeum Tüzvédelem, (1982), 8. 10-11.

Mol Médiaszoba: Baleset a MOL csepeli bázistelepén. 2010.

11 Az oxidáció, tűz és robbanásveszély elleni védelem, semleges gázokkal.

12 Tóth András: A bitumenfeldolgozás során történt tartályrobbanások és tűzesetek vizsgálata - I. rész. Hadmérnök, 13. (2018), 1. 217-229.; Tóth András: A bitumenfeldolgozás során történt tartályrobbanások és tűzesetek vizsgálata - II. rész. Hadmérnök, 14. (2019), 1. 220-230. 
etán, etilén, propán, i-bután, i-pentán. A felszabadult éghető gázok a szigetelés alatt túlmelegedtek és belobbantak. ${ }^{13}$

1. táblázat

A szénhidrogén-káresetek adatbázisából a tartályrobbanási tüzesetek lekérdezése.

Forrás: Tóth András 2020

\begin{tabular}{|c|c|c|c|c|c|c|c|c|}
\hline 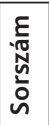 & Időpont & Esemény & Település & Helyszín, kiegészítés & $\begin{array}{l}\text { Káresemény } \\
\text { oka }\end{array}$ & $\begin{array}{l}\text { Anyagi } \\
\text { kár }\end{array}$ & : & 苍 \\
\hline 11 & 1950. 01. 01. & $\begin{array}{l}\text { Tartály- } \\
\text { robbanás }\end{array}$ & Ormándlak & 6-os tankállomás & Hegesztés & & 1 & 1 \\
\hline 28 & 1969. 01. 01. & $\begin{array}{l}\text { Tartály- } \\
\text { robbanás }\end{array}$ & Répcelak & $\begin{array}{l}\text { Szénsavtermelő Vállalat } \\
\text { telepén folyékony szén- } \\
\text { dioxidos tárolótartáy }\end{array}$ & $\begin{array}{l}\text { Hegesztési } \\
\text { varrat melletti } \\
\text { ridegtörés }\end{array}$ & & $6+13$ & 9 \\
\hline 30 & 1974. 08. 22. & Tartályégés & $\begin{array}{l}\text { Százha- } \\
\text { lombatta }\end{array}$ & $\begin{array}{l}\text { Százhalombatta DKV } \\
20000 \text { m³}^{3} \text {-es úszótetős } \\
\text { nyersolajtartály }\end{array}$ & Villámcsapás & & & \\
\hline 33 & 1979. 07. 11. & $\begin{array}{l}\text { Tartály- } \\
\text { robbanás }\end{array}$ & $\begin{array}{l}\text { Százha- } \\
\text { lombatta }\end{array}$ & $\begin{array}{l}\text { DKV bitumentöltő } \\
\text { parkjában az } 559 \text { sz. } \\
\text { bitumentartály }\end{array}$ & $\begin{array}{l}\text { A leürítés után } \\
\text { a maradék bitu- } \\
\text { men túlhevült }\end{array}$ & $191327 \mathrm{Ft}$ & & \\
\hline 35 & 1982. 05. 29. & $\begin{array}{l}\text { Tartály- } \\
\text { robbanás }\end{array}$ & $\begin{array}{l}\text { Százha- } \\
\text { lombatta }\end{array}$ & $\begin{array}{l}\text { Felső tároló területén } \\
\text { álló, 2014-es jelű } 2000 \\
\text { m³}^{3} \text {-es toluoltartály }\end{array}$ & Villámcsapás & 5,6 M Ft & & \\
\hline 36 & 1982.06. 09. & Tócsatüz & $\begin{array}{l}\text { Tiszaújvá- } \\
\text { ros }\end{array}$ & $\begin{array}{l}\text { Tiszai Finomító 60.002- } \\
\text { es számú tartály }\end{array}$ & $\begin{array}{l}\text { Leszakadt } \\
\text { keverőmotor } \\
\text { szikrája }\end{array}$ & & - & - \\
\hline 43 & 1985. 05. 08. & Tartályégés & $\begin{array}{l}\text { Százha- } \\
\text { lombatta }\end{array}$ & $\begin{array}{l}\text { Dunai Kőolajipari Vál- } \\
\text { lalat }\end{array}$ & Villámcsapás & & & \\
\hline 46 & 1986. 05. 28. & Tócsatüz & $\begin{array}{l}\text { Százha- } \\
\text { lombatta }\end{array}$ & $\begin{array}{l}\text { Dunai Kőolajipari Válla- } \\
\text { lat benzinfrakció üzem }\end{array}$ & $\begin{array}{l}\text { Refluxszivattyú } \\
\text { hibája }\end{array}$ & & & \\
\hline 51 & 1997. 04. 30. & Túzeset & $\begin{array}{l}\text { Százha- } \\
\text { lombatta }\end{array}$ & $\begin{array}{l}\text { Dunai Finomító } 5 \text { hely- } \\
\text { színen } 3 \text { tüzeset }\end{array}$ & Áramkimaradás & & & \\
\hline 61 & 2004. 04. 18. & Tócsatüz & $\begin{array}{l}\text { Százha- } \\
\text { lombatta }\end{array}$ & $\begin{array}{l}\text { Dunai Finomító AV-3 } \\
\text { üzem }\end{array}$ & Tömítési hiba & & & \\
\hline 63 & 2006. 11. 20. & $\begin{array}{l}\text { Tartály- } \\
\text { robbanás }\end{array}$ & Komárom & $\begin{array}{l}\text { Tartálytisztítás közben } \\
\text { egy } 2000 \text { köbméteres } \\
\text { oszloptartály }\end{array}$ & $\begin{array}{l}\text { Szabálytalan } \\
\text { munkavégzés }\end{array}$ & & $1+1$ & \\
\hline 64 & 2012.02. 02. & $\begin{array}{l}\text { Tartály- } \\
\text { robbanás }\end{array}$ & $\begin{array}{l}\text { Tiszaújvá- } \\
\text { ros }\end{array}$ & $\begin{array}{l}\text { OKT-10001 } \\
\text { szennyvíztároló tartály } \\
\text { palástjának felhasadása }\end{array}$ & Ismeretlen & & & \\
\hline 65 & 2010. 03. 25. & $\begin{array}{l}\text { Tartály- } \\
\text { robbanás }\end{array}$ & Csepel & $\begin{array}{l}\text { A MOL üzemanyag-tá- } \\
\text { roló telepén egy } 5000 \\
\text { m³}^{3} \text {-es benzintartály }\end{array}$ & $\begin{array}{l}\text { Szabálytalan } \\
\text { munkavégzés }\end{array}$ & & - & 1 \\
\hline 69 & 2016. 03. 17. & $\begin{array}{l}\text { Szigetelés } \\
\text { begyulla- } \\
\text { dása }\end{array}$ & Komárom & $\begin{array}{l}\text { Komárom Telep } 5014 \\
\text { jelü tartálya úszó- } \\
\text { tető-szigetelésének } \\
\text { begyulladása }\end{array}$ & $\begin{array}{l}\text { A tömítés le- } \\
\text { csúszása okozta }\end{array}$ & & & \\
\hline
\end{tabular}

13 Pátzay György: A tüzvizsgálat során feltárt bizonyitékok értékelése, a tüzkeletkezéssel kapcsolatos események elemzése, a lehetséges tüzkeletkezési okok megnevezése. Készült: Pátzay György és Tóth András e-mailben történt konzultációja alapján, feljegyzés, 2018. 
Tóth András, Siposné Kecskeméthy Klára, Endrődi István: A magyar szénhidrogéniparban...

\begin{tabular}{|c|c|c|c|c|c|c|c|c|}
\hline 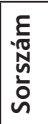 & Időpont & Esemény & Település & Helyszín, kiegészítés & $\begin{array}{l}\text { Káresemény } \\
\text { oka }\end{array}$ & $\begin{array}{l}\text { Anyagi } \\
\text { kár }\end{array}$ & : & 茞 \\
\hline 70 & 2018.07. 09. & $\begin{array}{l}\text { Tartály } \\
\text { szigetelése } \\
\text { égett }\end{array}$ & $\begin{array}{l}\text { Zalaeger- } \\
\text { szeg }\end{array}$ & $\begin{array}{l}\text { Zalai Finomító területén } \\
\text { telephellyel rendelkező } \\
\text { vállalkozás területén }\end{array}$ & Tartálytúltöltés & & & \\
\hline 71 & 2018. 11. 20. & Tüzeset & $\begin{array}{l}\text { Nagyhe- } \\
\text { gyes }\end{array}$ & $\begin{array}{l}\text { Magyar Földgáztároló } \\
\text { Zrt. földalatti gáztároló } \\
\text { üzem }\end{array}$ & $\begin{array}{l}\text { Technológiai } \\
\text { meghibásodás }\end{array}$ & & & \\
\hline
\end{tabular}

\section{Gázrobbanás, vezetékhasadás}

Ez a fejezet a feldolgozás és a szénhidrogéntermékek szállításának baleseteit foglalja össze. A szénhidrogéntermékek, halamazállapottól független legbiztonságosabb módja a vezetékes szállítás. Két jelentősebb esemény történt a feldolgozott időszakban.

\section{8, Százhalombatta}

1968. október 16-án a DKV AV-II. desztillációs üzemében a sikeresen lefolytatott próbaüzem után, a leállást követő üzemindításkor, a barometrikus kondenzátoron keresztül szabadba jutó könnyü szénhidrogéngázok a csőkemencét elérve belobbantak, két személy súlyos égési sérülést szenvedett. A segítségükre siettek a szakemberek és a vállalati tüzoltók, de egy újabb gázrobbanás következett be, amelyet folyamatos égés követett. 16 fő súlyos sérüléseket szenvedett, később 8 fő elhunyt. A káresetet követően került sor a szénhidrogén-koncentrációt érzékelő és azt jelző eszközök kiépítésére és a csőkemencék gőzfüggönnyel történő leválasztására. ${ }^{14}$

\section{9, Püspökladány külterülete}

2019. november 18-án vezetékhasadás történt hajnalban egy gázfogadó állomásnál Püspökladány külterületén, a 42-es föút közelében. A kiáramló gáz meggyulladt, és nagy lánggal égett. A tüz a környező nádasra is átterjedt, az foltokban égett. A káresethez a püspökladányi, a debreceni, a hajdúszoboszlói, a karcagi és a berettyóújfalui hivatásos tüzoltók vonultak nagy erőkkel. A munkálatokat a katasztrófavédelmi múveleti szolgálat irányította. A sérült vezetéket elzárták, a lángok mérete, kiterjedése ennek hatására csökkent, majd megszünt. A tűz nemcsak a környező növényzetre terjedt át, hanem körbálák is meggyulladtak. A katasztrófavédelmi mobil labor folyamatosan mérte a gázkoncentrációt. A tűzoltók és gázszolgáltató szakemberei a sérült gázvezeték mellett a másik vezetéket is megvizsgálták, hogy nem sérült-e meg. ${ }^{15}$

14 Vincze István - Gyollai József: Tanulmány a százhalombattai DKV. 2 Mt/év. ÁV. Desztillációs üzem területén 1968. október 16-án 9:46-kor keletkezett tüzesetről. Tüzoltó Múzeum, 1968. 1-13.

15 Papp-Kunkli Nóra: Vezetékhasadás történt Püspökladány külterületén. 2019. november 18. 
A FGSZ Zrt. (a továbbiakban: Társaság) által elrendelt vizsgálat eredményei szerint a vezeték fő meghibásodási okai elsősorban a nyolcvanas években történt kivitelezés minőségére vezethetők vissza. A vizsgálati eredményekre alapozva a Társaság megtette a szükséges intézkedéseket a soron kívüli felülvizsgálat eljárásrendjének kidolgozására és lefolytatására. Ennek részeként a Társaság beazonosította és feltárta a meghibásodott vezeték kritikus szakaszait, az ott található hegesztési körvarratok roncsolásmentes anyagvizsgálatát elvégezte, és azt kompozit bilinccsel megerősítette. Emellett a Társaság elrendelte a teljes nagy nyomású földgázvezeték-rendszerre vonatkozóan a jelenleg használt vezetékdiagnosztikai eljárások körének felülvizsgálatát és azok nemzetközi szabványokon és tapasztalatokon alapuló kibővítését, valamint az építés, szerelés követelményeire vonatkozó, további szigorító müszaki előírások azonnali bevezetését. A baleset ráirányította a figyelmet arra, milyen fontos szerepe van a vezeték környezetében a jogszabály által előírt és megkövetelt biztonsági övezetnek - amelyen belül tilos többek között az építési, tűzrakási tevékenység, a vezeték állapotát veszélyeztető maró- és tüzveszélyes szerek kiöntése vagy kiszórása és anyagok lerakása -, hiszen főként ennek a biztonsági övezetnek volt köszönhető, hogy nem keletkezett nagyobb kár a sérült vezeték közvetlen környezetében. A lakosság védelme érdekében a Társaság újra felülvizsgálja a biztonsági övezetekre vonatkozó jogszabályok betartását a teljes magyarországi nagy nyomású földgázvezeték rendszer mentén. A vizsgálat a szabálytalanságok feltárását és megszüntetését célozza, ezáltal is növelve a biztonságot. ${ }^{16}$

\section{A megelőzés és a rendkívüli események kezelése}

\section{Dolgozz hibátlanul!}

A megelőzés fontos részeként az olajiparban már 1971-ben felmerült a dolgozz hibátlanul (DH) munkarendszer bevezetésének és alkalmazásának gondolata. Alkalmazásának feltételei: a vezetők és beosztottak oktatása, a meglévő hibák és hibaforrások feltárása, a rendszer alkalmazásához szükséges személyek és eszközök és megfelelő ösztönzési rendszer. Az első évben 280 hibajelzés, javaslat érkezett, az ötödik év végére a szám 1777-re emelkedett. Az anyag- és energiamegtakarítás jelentős, az ötletgazdáknak magas jutalom került kifizetésre. ${ }^{17}$

\section{Aarhusi egyezmény ${ }^{18}$}

Mógor Judit már a 2010-es értekezésében rávilágított arra, hogy az Aarhusi Egyezmény és a 2003/4/EK irányelvhez kapcsolódó 2001. évi LXXXI. törvény végrehajtásának záloga az Egyezmény környezeti joghoz kapcsolódó jogszabályokba történő átültetése lesz, ami elsősorban a különböző környezetvédelmi eljárások normáit, továbbá egyes katasztrófavédelmi engedélyezési szabályokat jelenti.

16 FGSZ Zrt.: Lezárult a vizsgálat a tavaly novemberben bekövetkezett püspökladányi földgázvezetéken keletkezett tüzel kapcsolatban. 2020.

17 Ötven éves a magyar kőolaj- és fölgázbányászat. Nagyalföldi Kőolaj és Földgáztermelő Vállalat Nyomda Üzem, 1987.

18 Egyezmény a környezeti ügyekben az információhoz való hozzáférésről, a nyilvánosságnak a döntéshozatalban történő részvételéről és az igazságszolgáltatáshoz való jog biztosításáról. 
Úgy gondolta, hogy a súlyos ipari balesetek elleni védekezéshez kapcsolódó eljárásokban is alkalmazni kell az Egyezmény előírásait, vagyis a felsorolt tevékenységek engedélyezési eljárása során hozandó döntésekben a „Részes Felek" betartják a nyilvánosság részvételére vonatkozó szabályokat. A tevékenységek listájában ott szerepeltek az ásványolaj- és gázfinomítók, a kereskedelmi célú nyersolaj- és földgázkivétel, az olaj, petrolkémiai vagy vegyi termékek tárolására alkalmas létesítmények.

Véleménye szerint, a felsorolt szénhidrogénipari tevékenységek során alkalmazott veszélyes anyagok megalapozzák a létesítmények a korábbi Seveso II. irányelv, valamint Ipari Baleseti ENSZ EGB Egyezmény magyarországi végrehajtását biztosító hazai jogszabályok hatálya alá tartozást, tehát a veszélyes ipari üzemekkel kapcsolatos hatósági eljárásokban érvényesíteni kell az Aarhusi Egyezmény előírásait. ${ }^{19}$

\section{A rendkívüli események kezelése}

Az innovációért és technológiáért felelős miniszter 39/2019. (X. 31.) utasítása szabályozza a rendkívüli események kezelésének rendjét, amely meghatározza a kormányügyeleti rendszer minisztériumi feladatait. Az utasítás többek között meghatározza a rendkívüli esemény fogalmát az országot és a lakosságot érintő, az Alaptörvény 48-53. cikkében foglaltak, valamint a külföldön tartózkodó magyar állampolgárok biztonságát súlyosan veszélyeztető helyzet esetén.

Az ágazatok vonatkozásában kormányzati intézkedést igénylő rendkívüli események jegyzéke alapján a Magyar Bányászati és Földtani Szolgálat jelentési területén jelenteni kell:

- szénhidrogén-bányászat, -tárolás és -szállítás területén egyidejüleg legalább négy halálesettel vagy súlyos sérüléssel vagy nagymérvű környezeti károkozással járó: kútkitörés (gáz, kőolaj, $\mathrm{CO}_{2}$ ), földgáztároló-sérülés, szállítóvezeték-sérülés, -robbanás;

- gázszolgáltatás területén Pb-töltőüzem, elosztó vezeték, illetve gázátadó-gázfogadó állomáson egyidejüleg legalább négy halálesettel vagy súlyos sérüléssel járó szivárgás, vagy robbanás. ${ }^{20}$

\section{A Gazdasági Együttmüködési és Fejlesztési Szervezet megelőzéssel kapcsolatos irányelvei}

A korábbi elavult szabályozó rendszerek EU-normáknak való megfeleltetése az elmúlt évtizedek során Magyarországon is megtörtént. A SEVESO I. - SEVESO III. irányelvek alapján a veszélyes anyagokkal kapcsolatos súlyos baleseti veszélyek szabályozásában meghatározott alapelvek az Európai Unió országaiban az ipari és környezeti biztonság egyik alapdokumentumává vált. A veszélyes anyagokkal kapcsolatos súlyos

19 Mógor Judit: A lakossági tájékoztatás és a nyilvánosság biztosításának kutatása a súlyos ipari balesetek elleni védekezésben. Doktori értekezés, Budapest, ZMNE, KMDI, 2010. 133.

20 Az innovációért és a technológiáért felelős miniszter 39/2019. (X. 31.) ITM utasítása a kormányzatügyeleti rendszer minisztériumi feladatainak meghatározásáról, 1. melléklet a 39/2019 (X. 31.) ITM utasításhoz, az innovációért és a technológiáért felelős miniszter által felügyelt ágazatok vonatkozásában kormányzati intézkedést igénylő rendkívüli események jegyzéke. 
balesetek megelőzésére vonatkozó, a katasztrófák kezelésére szerveződött intézmények tevékenységét szorosan érintik a Gazdasági Együttmüködési és Fejlesztési Szervezet (Organization for Economic Co-operation and Development, a továbbiakban: OECD) idevonatkozó irányelvei. Az OECD egy kormányközi szervezet, amelyben 38 észak- és dél-amerikai, európai és ázsiai és csendes-óceáni térség iparosodott országának képviselői, valamint az Európai Bizottság tagjai találkoznak, együttműködnek, és harmonizálják az aktuális szakpolitikákat, irányelveket. Megvitatják a kölcsönös érdeklődésre számot tartó kérdéseket, és együttműködnek a nemzetközi problémák megoldása érdekében. Az OECD munkájának nagy részét több mint 200 speciális bizottság és munkacsoport végzi, amelyek a tagországok képviselőiből állnak. Az OECD speciális státusú országok és az érdekelt nemzetközi szervezetek megfigyelői vesznek részt az OECD számos mủhelyén és egyéb találkozóin. A bizottságokat és munkacsoportokat az OECD Titkársága látja el, amely Párizsban található, Franciaországban, és igazgatóságokra és osztályokra tagolódik, Magyarország 1996 óta tagja.

\section{Felkészültség}

Fontos megemlíteni az OECD 2018. évi 30-as számú kiadványában rögzített, a szénhidrogén-feldolgozás során alkalmazható kémiai balesetek megelőzésével kapcsolatos munkacsoportjának fő következtetéseit a kémiai balesetek megelőzésére, a felkészültségre és a reagálásra vonatkozó rendeletek lehetséges előnyeinek meghatározására. A 8-as pont szerint a vegyi balesetek megelőzésére, felkészültségére és reagálására vonatkozó rendeletek elsődleges célja a balesetek megelőzése és a bekövetkező balesetek hatásainak csökkentése, ami magában foglalja a veszélyhelyzethez kapcsolódó kockázatkezelési terveket a veszélyeztetett üzemek és a lakosság számára. A kockázatkezelési tervek alapján elkerült védekezés költségei haszonként lépnek fel. Idetartoznak a számszerüsíthető adatok és a minőséget jelző adatok. A munkacsoport kihangsúlyozta, hogy a felmerülő költségek, előnyök és a „haszon" leírása és értékelése segíthet a döntéshozatal szabályozásában és az irányelvek kidolgozásában. Segítene megérteni a balesetek negatív gazdasági hatását az országoknak és az ipar számára. A felkészültség olyan intézkedésekre összpontosít, amelyek lehetővé teszik a balesetek megfelelő reagálását. Példa erre a balesetekre való felkészülési tervek kidolgozása, a korai előre jelző intézkedések, a nyilvánossággal való kommunikáció és a vészhelyzeti gyakorlatok. ${ }^{21}$

\section{A megelőzés és ellenőrzés rendelkezésre álló legjobb technikái}

Az OECD 2019-es Környezetvédelmi Főigazgatóság vegyi anyagokkal kapcsolatos ülésén a rendelkezésre álló legjobb technikák (Best Available Techniques, a továbbiakban: BAT $)^{22}$ az ipari szennyezés megelőzése és ellenőrzése hatékonyságmérés házirendjét vizsgálta a 3. számú cselekvési tervében. Az ipari szennyezés megelőzésével

21 Workshop Report: Developing a Methodology to Quantify the Benefits of Regulations for Chemical Accidents Prevention, Preparedness and Response, OECD Environment, Health and Safety Publications Series on Chemical Accidents. No. 30. Paris, 2018. Environment Directorate OECD.

22 Best Available Techniques - Elérhető legjobb fogások, technikák, beleértve a technológiát, a tervezést, karbantartást, üzemeltetést és felszámolást, amelyek elfogadható műszaki és gazdasági feltételek mellett gyakorlatban alkalmazhatók, és a leghatékonyabbak a környezet egészének magas szintű védelme szempontjából. 
és csökkentésével kapcsolatos irányelvek jelentős környezeti, pénzügyi és emberi egészségi előnyökkel járhatnak. Egyre több ország használja a rendelkezésre álló BAT-ot az ipari kibocsátási szintek megállapításához, amelyek bizonyítékokon és több érdekelt fél közötti párbeszéden alapulnak. A BAT-irányelvek megbízható eszközök a világ legszennyezőbb iparágainak kibocsátásának megakadályozására vagy csökkentésére. Ezenkívül eszközként szolgálnak az ipari tevékenységek környezeti hatásainak szélesebb körű kezelésére, például kiigazított erőforrás-felhasználás, hulladékkezelés, mérgező anyagok helyettesítése és a továbbfejlesztett gyártási folyamatok révén, miközben minimalizálják azokat a hatásokat, amelyek akadályozhatják a normál müködést.

A BAT-alapú irányelvek hatékonyságának értékelése elengedhetetlen azok hatásának erősítéséhez és a jövőbeni irányelvek kialakításához. Ennek hiányában a kormányok időt és forrásokat pazarolnak a nem hatékony környezetvédelmi irányelvek végrehajtására. A BAT-irányelvek hatásainak megértése és értékelése révén a kormányok tájékozódhatnak és kidolgozhatnak testreszabott, hatékonyabb kibocsátási határértékeket az ipari létesítmények engedélyében. Az értékelési gyakorlat megkönnyítheti a kulcsfontosságú érdekelt felekkel és a nyilvánossággal folytatott fokozott kommunikációt a BAT-irányelvek célkitüzéséről, müködéséről és hatásáról. A BAT-irányelvek értékelése lehetővé teszi a múltbeli intézkedések hatásának mérését, valamint a jövőbeni döntések megerősítését. A BAT-irányelvek kiértékelése a kormányok és a nyilvánosság számára egyaránt előnyös, mivel elősegíti a jobb megoldások kidolgozását, azaz tájékoztatja és megkönnyíti a hatékonyabb és testreszabottabb BAT és kibocsátási határértékek kidolgozását az engedélyekben. Hatásvizsgálatokra is szükség van a BAT-irányelvek céljának és hatásának bemutatása és az érdekelt felek, köztük az ipar, a politikai döntéshozók és a nyilvánosság tájékoztatása érdekében. ${ }^{23}$

\section{A rendelkezésre álló legjobb technikák alkalmazása a szénhidrogéniparban}

A feltárt káresemények óriási hatást gyakoroltak környezetükre, gondoljunk az elsülylyedt berendezésekre, a kitörések során a környező mezőre épületekre szóródott olajos földre, a területre kifolyt olajra, a légkörbe szökő gázra, a fekete füsttel égő olajtartályokra stb. A szénhidrogéniparral kapcsolatos környezetvédelmi elvárásokat a 314/2005. (XII. 25.) Korm. rendelet a környezeti hatásvizsgálati és az egységes környezethasználati engedélyezési eljárás foglalja össze. Példaként megvizsgáltuk a Csongrád Megyei Kormányhivatal által kiadott egységes környezethasználati engedélyét a Szanki Földgázüzem-Dúsító földgázkitermelés éves tevékenység folytatásához. A Szank Földgázüzem-Dúsítóban folyó tevékenység BAT szerinti értékelését a 314/2005 (XII. 25.) Korm. rendelet szerint végezte el az engedéllyel rendelkező. Az alkalmazott technológia és a hozzá kapcsolódó tevékenységek BAT szerinti megítélése az Európai Bizottság által kiadott: „A környezetszennyezés integrált megelőzése és csökkentése;

23 Environment Directorate Joint Meeting of the Chemicals Committee and the Working Party on Chemicals, Pesticides and Biotechnology, Best Available Techniques (BAT) for Preventing and Controlling Industrial Pollution Activity 3: Measuring the Effectiveness of BAT Policies Organisation for Economic Co-operation and Development. ENV/JM/ MONO (2019) 21, 2019. június 07. 
Összefoglaló Referencia dokumentum a tárolásból eredő kibocsátásokhoz kapcsolódóan elérhető legjobb technikákról" címü dokumentum kőolaj- és gázfinomítókra vonatkozó megállapításai (STO, ${ }^{24} 2005$. január), valamint a hazai sajátosságok figyelembevételével és a hatályos jogszabályok alapján történt. A vertikális elemzés során a szintén a Környezetvédelmi és Vízügyi Minisztérium által készíttetett Útmutató az elérhető legjobb technika meghatározásához az energiahatékonyság terén (ENE, ${ }^{25} 2008$. július), valamint az Európai Bizottság által kiadott Referenciadokumentum a monitoring általános alapelveiről ( $M O N,{ }^{26}$ 2003. július) megállapításait vették figyelembe. A MOL Nyrt. tevékenységének szabályozására bevezetett, müködtetett és folyamatosan fejlesztett szabványos irányítási rendszerek: minőségirányítási rendszer (MIR); ISO 9001:2008; energiairányítási rendszer; munkahelyi egészségvédelmi és biztonsági irányítási rendszer (MEBIR); OHSAS 18001:2007; fentiek szerinti szervezetalapú, folyamatközpontú integrált irányítási rendszer.

A rendelkezésre álló legjobb technikák alkalmazásával kapcsolatos előírások Az engedéllyel rendelkezőnek, mint környezethasználónak a környezetszennyezés megelőzése, illetőleg a környezet terhelésének csökkentése érdekében, az elérhető legjobb technika alkalmazásával a tevékenységet úgy kell végezni, a berendezéseket úgy kell múködtetni, hogy a kibocsátásai megfeleljenek az egységes környezethasználati engedélyben foglaltaknak.

Az engedéllyel rendelkezőnek az elérhető legjobb technika alkalmazásával intézkedni kell:

- a tevékenységhez szükséges anyag és energia hatékony felhasználásáról,

- a kibocsátások megelőzéséről, illetőleg az elérhető legkisebb mértéküre csökkentéséről,

- a hulladékképződés megelőzéséről, illetőleg a keletkezett hulladék mennyiségének és veszélyességének csökkentéséről,

- a környezeti hatással járó balesetek megelőzéséről és ezek bekövetkezése esetén a környezeti következmények csökkentéséről,

- a tevékenység felhagyása esetén a környezetszennyezés, illetve környezetkárosítás megakadályozásáról, valamint az esetlegesen károsodott környezet helyreállításáról,

- valamint arról, hogy minimumra csökkenjenek a létesítmény müködésére visszavezethető zavaró környezeti hatások, illetve veszélyek fellépésének lehetősége.

A technológiai vezetékek és berendezések karbantartását rendszeresen el kell végezni. A telephelyen folytatott tevékenység során az elérhető legjobb technika alkalmazásával meg kell akadályozni, hogy a földtani közeg szennyeződjön. Az engedéllyel

24 Techniques for Emissions from Storage - A tárolásból eredő kibocsátások technikája.

25 Best Available Techniques for Energy Efficiency - Az energiahatékonysághoz rendelkezésre álló legjobb technikák.

26 Reference Document on General Principles of Monitoring - Referenciadokumentum a monitoring általános alapelveiről. 
rendelkező köteles a létesítményben alkalmazott technológiát a mindenkor elérhető legjobb technika követelményeinek megfelelően üzemeltetni.

Az éves környezeti beszámolókat minden év március 31-ig kell elkészíteni a hulladékgazdálkodás, keletkezett hulladékok és a technológiánkénti anyagmérleg, valamint a levegővédelem, elvégzett mérések és azok értékelése - BAT-megfelelés vizsgálatához. Eseti beszámolót az üzemzavarok jelentésére haladéktalanul, az energetikai belső auditáláshoz (veszteségfeltáró vizsgálat) 5 évente kell elkészíteni. Ezenkívül a BATnak való megfelelőség elemzést 5 évente, a felülvizsgálati dokumentáció részeként kell mellékelni. ${ }^{27}$

A szénhidrogén-feldolgozás során elsősorban a gőzkrakkoló kemencék okoznak szennyezőanyag-kibocsátást. A legjelentősebb szennyező anyagok itt a NOx és az illékony szerves vegyületek. Az alacsony NOx-kibocsátású égők alkalmazásának köszönhetően az elmúlt években csökkent a NOx-kibocsátás, a VOC-kibocsátás csökkentése érdekében pedig egy projekt keretében az úszótetős tartályokat rögzített tetővel látták el. A Petrolkémiai üzletág minden egyes müködési folyamata megfelel a BAT követelményeinek. ${ }^{28}$

\section{A SEVESO III. biztonsági irányítási rendszerrel kapcsolatos változások}

Vass Gyula és társai a módosuló jogszabályi előírások végrehajtásához kidolgozott útmutatóban ajánlásokat fogalmaztak meg a SEVESO III. irányelv hazai bevezetésével a jogi szabályozásba bekerült új előírások teljesítésére.

Az OECD-útmutató hét lépésben határozza meg a biztonsági teljesítménymutatók rendszerének kialakítását:

1. a teljesítménymutatók rendszerének kialakításáért felelős csapat létrehozása,

2. kulcsfontosságú kérdések azonosítása,

3. eredményindikátorok és mértékegységük meghatározása,

4. tevékenységindikátorok és mértékegységük meghatározása,

5. adatgyújtés és jelentés készítése,

6. cselekvés az indikátorok tükrében,

7. értékelés és a teljesítménymutatók finomítása.

Megállapították, hogy valamennyi ipari szereplő esetében alkalmazható biztonsági teljesítménymutatókat egy útmutatóban nem lehetséges meghatározni. A biztonsági irányítási rendszer (a továbbiakban: BIR) hatékonyságának eredményes mérése érdekében a tartalmi elemekhez rendelt valamennyi biztonsági célkitüzéshez kapcsolódóan legalább 1-2 indikátor mérése és nyomon követése szükséges.

Leírták többek között, hogy a biztonsági teljesítménymutatók értékeléséből származó eredmények, beleértve a türéshatárok túllépését, a zavaró tendenciák hosszú ideig történő fennállását és az esetlegesen következetlen eredményeket, utóintézkedéseket követelnek meg. Ellenkező esetben nincs sok értelme végrehajtani a programot. A legfontosabb információkat tartalmazó előre meghatározott időközönként készített

\footnotetext{
MOL Nyrt., Szank, egységes környezethasználati engedély. 2016

28 MOLGROUP: Fenntarthatóság, környezet.
} 
jelentéseknek el kell jutnia a felsővezetőkhöz, a biztonsági szervezethez, a mérnökökhöz és egyéb érintett munkavállalókhoz. Ezek az információk a legfontosabbak a kedvezőtlen eredmények gyors nyomon követése, a biztonsági célkitüzések, eljárások és folyamatok feltárt hiányosságainak mielőbbi kijavítása érdekében. A programot (beleértve a jelzőket és a mérőszámokat is) rendszeres időközönként értékelni és felülvizsgálni szükséges. Az áttekintés során az indikátorok meghatározásai pontosíthatók, új területek adhatók a programhoz és egyes biztonsági kérdések megválaszolhatók. Ezen túlmenően a felülvizsgálat eredményeként egyes különleges indikátorok elhagyhatók, és a program a legfontosabb biztonsági kérdések vizsgálatára fókuszálható. ${ }^{29}$

\section{6. Összefoglalás}

A szerzők véleménye szerint a szénhidrogén-feldolgozás során legfontosabb a káreseményre felkészülés és a megelőzés. A felkészülés a katasztrófavédelem valamennyi integrált szakterület munkáját érinti hatósági, iparbiztonsági, polgári védelmi, de a káreseti szituációk begyakorlása a készenléti állomány a müveletirányítás Katasztrófavédelmi Müveleti Szolgálat és Katasztrófavédelmi Mobil Labor tevékenységét nagymértékben megkönnyíti éles helyzetben.

Az ember és az alkalmazott technológia, ez a megelőzés alapja. A hibás technológián lehet és kell is finomítani, csiszolni, megérteni, felkészülni, cselekedni és megelőzni. A katasztrófák megértése, elemzése, kivédése, a következmények mérséklése csak úgy lehetséges, ha a fenti szempontok mindegyikét vizsgáljuk. A katasztrófák leírása és a következtetések levonása nem egyszerü, nem mindenki képes arra, hogy globálisan, ok-okozati összefüggések láncolatán át lássa és érzékelje. Az elemzéshez több szakma ismerete és összekapcsolása szükséges. Az okok kiderítése néha szövevényesen bonyolult.

A szénhidrogén-feldolgozás folyamatainak fejlesztésére a biztonság növelésére Tóth András, első szerző az alábbi javaslatokat teszi:

- Az elvárt alapminőség elérése a folyamatok támogatásával.

- A karbantartások tervezett módon történjenek.

- Egységes szervezeti és gyártási struktúra, kultúra kialakítása.

- Folyamatalapú munkaszervezés, munkavégzés.

A kivitelezéseket, karbantartásokat végzők folyamatos képzése és ellenőrzése az egyik legfontosabb feladat, mivel a legtöbb esemény a nem megfelelő munkavégzésből fakad.

A leírt jogszabályi törekvések és a vállalati stratégiák elmozdultak az emberi tevékenység kontrollálásának irányába, de amíg nem jelennek meg jelentős mértékben a BIR-ben, marad a jól bevált hatósági, szakhatósági, vagyis a katasztrófavédelem és a biztonságtudományok által nyújtott, de folyamatosan felülvizsgált jogszabályok védelme.

29 Vass Gyula - Mesics Zoltán - Kovács Balázs: Útmutató a biztonsági irányítási rendszerekkel kapcsolatban a SEVESO III. irányelv hazai bevezetésével módosuló jogszabályi előírások végrehajtásához. Belügyminisztérium Országos Katasztrófavédelmi Főigazgatóság, Országos Iparbiztonsági Főfelügyelőség, Veszélyes Üzemek Főosztály, 2016. március. 
Tóth András következtetése alapján egyetlen végleges megoldás létezik a szénhidrogén-feldolgozók mint ember által üzemeltetett rendszerek káreseteinek elkerülésére a technológiai folyamatok még szigorúbb betartásán felül: az emberi döntésektöl és hibáktól, egyszóval az élőmunkamentes vezérlési rendszer és termelési folyamatok (foolproof) ${ }^{30}$ vagy a hibaelkerülési (poka-yoke) ${ }^{31}$ rendszerrel megtervezett és vezérelt folyamatok kialakítása és müködtetése.

A foolproof egy működő rendszerben kizárja annak a hibás emberi döntésnek a végrehajtását, ami például egy vezérlőszelep kinyitásával robbanást idézhet elő. A program és az algoritmus folyamatosan elemzi a rendszer stabilitását, és nem engedi a művelet végrehajtását. De az ember leleményes, kilép a vezérlőhelyiségből, odamegy, és elfordítja a szelep nyitókarját, de a „bolondbiztos” rendszer eljárása érzékeli a nyomásesést, leállítja a teljes folyamatot, így a robbanás elmarad. A rendszerrel nemcsak a hibás döntés, de egy szabotázs is kivédhető.

A poka-yoke megoldás megelőzi a hiba előfordulását azzal, hogy az előre megtervezett folyamatot elemezve felkészülnek és számítanak az emberi hibázás lehetőségére, ezért egy kizárólag elektronikusan vezérelhető szelepet építenek be a rendszerbe, amelyen nincs nyitókar, Így mechanikusan nem lehet megnyitni, tehát a detonáció elkerülhető.

A két módszer közül az adott terültre legkézenfekvőbbet választva érhető el a legnagyobb biztonság, kizárva a cikksorozatban felvonultatott emberi hibákból és mulasztásokból, hibás döntésekből, anyaghibákból eredő szénhidrogénipari balesetek megismétlődését.

\section{Felhasznált irodalom}

BFH Európa Kft.: Répcelak Város Településfejlesztési Koncepciója. 2015. Online: http:// repcelak.hu/editor_up/Repcelak\%20Varos\%20Megalapozo\%20vizsgalat.pdf

Environment Directorate Joint Meeting of the Chemicals Committee and the Working Party on Chemicals, Pesticides and Biotechnology, Best Available Techniques (BAT) for Preventing and Controlling Industrial Pollution Activity 3: Measuring the Effectiveness of BAT Policies Organisation for Economic Co-operation and Development. ENV/ JM/MONO (2019) 21, 2019. június 07. Online: www.oecd.org/officialdocuments/ public displaydocumentpdf/?cote=ENV/JM/MONO(2019)21\&docLanguage=En

FGSZ Zrt.: Lezárult a vizsgálat a tavaly novemberben bekövetkezett püspökladányi földgázvezetéken keletkezett tüzel kapcsolatban. 2020. Online: https://fgsz.hu/ vallalatunk/hirek/lezarult-a-vizsgalat.html

Jáni János: A nyugdijas gellénházi olajipari szakember visszaemlékezése a gáz és tartályrobbanásra. Készült Jáni János és Tóth András telefonos megbeszélése alapján, feljegyzés, Zalaegerszeg, 2019. szeptember 18.

Kiss Imre: Tartályégetés Százhalombattán. Tüzoltó Múzeum Tüzvédelem, (1982), 8. 10-11. Kurucz István: Indulatok nélkül. A répcelaki robbanásról. Zalaegerszeg, Magyar Olajipari Múzeum Közleményei, 2009.

30 „Bolondbiztos” az emberi hibáktól, döntésektől mentes vezérlési rendszer.

31 Hibaelkerülés, a japán vállalatszervezési gondolatrendszer eleme, közel 0-ra csökkenti az emberi hiba esélyét. 
Tóth András, Siposné Kecskeméthy Klára, Endrődi István: A magyar szénhidrogéniparban...

Mógor Judit: A lakossági tájékoztatás és a nyilvánosság biztosításának kutatása a súlyos iparibalesetek elleni védekezésben. Doktori értekezés, Budapest, ZMNE, KMDI, 2010.

Mol Médiaszoba: Baleset a MOL csepeli bázistelepén. 2010. Online: https://mol.hu/ hu/molrol/mediaszoba/858-baleset-a-mol-csepeli-bazistelepen/

MOL Nyrt., Szank, egységes környezethasználati engedély. 2016. Online: http://bkmkh. hu/uploads/kornyezetvedelmih/Mol_Nyrt._Szank.pdf

MOLGROUP: Fenntarthatóság, környezet. Online: https://molgroup.info/hu/fenntarthatosag/kornyezet

Ötven éves a magyar kőolaj- és fölgázbányászat. Nagyalföldi Kőolaj és Földgáztermelő Vállalat Nyomda Üzem, 1987.

Papp-Kunkli Nóra: Vezetékhasadás történt Püspökladány külterületén. 2019. november 18. Online: https://hajdu.katasztrofavedelem.hu/24545/hirek/217857/vezetekhasadas-tortent-puspokladany-kulteruleten\#lg=1\&slide $=0$

Pátzay György: A tüzvizsgálat során feltárt bizonyítékok értékelése, a tüzkeletkezéssel kapcsolatos események elemzése, a lehetséges tüzkeletkezési okok megnevezése. Készült: Pátzay György és Tóth András e-mailben történt konzultációja alapján, feljegyzés, 2018.

Tóth András - Muhoray Árpád - Pellérdi Rezső: Magyarország jelentősebb ipari katasztrófái a veszélyhelyzet tervezés és kezelés szempontjából. Müszaki Katonai Közlöny, 29. (2019), 2. 21-39. Online: https://doi.org/10.32562/mkk.2019.2.2

Tóth András: A bitumenfeldolgozás során történt tartályrobbanások és tűzesetek vizsgálata - I. rész. Hadmérnök, 13. (2018), 1. 217-229. Online: http://hadmernok. hu/181_17_toth.pdf

Tóth András: A bitumenfeldolgozás során történt tartályrobbanások és tűzesetek vizsgálata - II. rész. Hadmérnök, 14. (2019), 1. 220-230. Online: http://hadmernok.hu/191_18_toth.pdf

Vass Gyula - Mesics Z̄oltán - Kovács Balázs: Útmutató a biztonsági irányítási rendszerekkel kapcsolatban a SEVESO III. irányelv hazai bevezetésével módosuló jogszabályi előírások végrehajtásához. Belügyminisztérium Országos Katasztrófavédelmi Főigazgatóság, Országos Iparbiztonsági Főfelügyelőség, Veszélyes Üzemek Főosztály, 2016. március. Online: www.katasztrofavedelem.hu/application/uploads/ documents/hat-veszuz-szaktaj/740.pdf

Vincze István - Gyollai József: Tanulmány a százhalombattai DKV. 2 Mt/év. ÁV. Desztillációs üzem területén 1968. október 16-án 9:46-kor keletkezett tüzesetről. Tüzoltó Múzeum, 1968. 1-13.

Workshop Report: Developing a Methodology to Quantify the Benefits of Regulations for Chemical Accidents Prevention, Preparedness and Response, OECD Environment, Health and Safety Publications Series on Chemical Accidents. No. 30. Paris, 2018. Environment Directorate OECD. (Mühelytájékoztató: Módszertan kidolgozása a vegyi balesetek megelőzésére, a felkészültségre és a reagálásra vonatkozó rendeletek előnyeinek számszerúsítésére 30. számú kémiai balesetek sorozata.) Online: www.oecd.org/officialdocuments/publicdisplaydocumentpdf/?cote=env/ $\mathrm{jm} / \mathrm{mono}(2018) 3 \&$ doclanguage $=$ en 